\title{
Corps raciology and cultural relativism
}

Keywords: Corps, raciology, cultural, relativism, race, anthropology

\section{Introduction}

Cultural relativism is born historically called the American culturalist anthropology, between the two world wars, opposed mainly German. It clung to classify human "races" in order to emphasize the Aryan. The discovery of the Nazi genocide, after the Nuremberg Trials, presented deeply question the idea of "race". ${ }^{1}$ The international committees and the various pronouncements that followed these trials have sought to promote three ideals. First, the universal nature of human rights that should apply to the whole of humanity. Then, consideration and respect for all ethnic and cultural formations, of which sought to establish equality. Finally, the regulation of experiments on the human body, while requiring the voluntary consent of the subject. The development of the second ideal in the form of cultural relativism, did not fail to clash with the first and third ideals., ${ }^{2,3}$ On the one hand the Universalist claims of ethics related to human rights, does not sit well with the cultural relativity of values. Moreover, respect for the human body and the person are often contradicted by numerous regional customs. Let's try to understand what the historical and theoretical foundations of cultural relativism are. Then try to assess the conceptual content of ethical relativism. Finally, analyze the type of reports that anthropology has with bioethics.

It may be recalled that Kant describes anthropology from a pragmatic point of view, highlighting a double paradox. The first is that the human knowledge is always individualized, and endeavors to describe the concrete characteristics. However, it presupposes the same time a general knowledge without which the study is still only fragmentary, unable to claim the status of science. The second paradox concerns the necessarily interpretative nature of anthropological investigation, resulting from the fact that observation is never that of the man as he is, but only as it appears to the observer, and according the terms that the observed helping to bring. ${ }^{4}$ If this double paradox persisted well after Kant, however, then it seems to have moved somewhat to the epistemological axiological plane when the anthropologist sought to identify the cultural universe of each population studied and the consideration of values it conveys. Note the role has had in such a displacement, Herder, a contemporary of Kant, who in 1774 denounced the folly of European universalism involving contempt for other cultures. ${ }^{5}$

In fact, as recalled Dumont, this tension between universalism and particularism is consubstantial to anthropology itself. It defines two poles, the combination of which is the source of inextricable difficulties. ${ }^{6,7}$ These have arisen since the sixteenth century, with the beginning of colonization that prompted the Europeans to realize the strangeness body body-other non-Western, trying to locate the connection had a standard res of universal humanity. Until the eighteenth century, the body (of) alien is gauged based on the concept of "race". First associated with the idea of purity, the concept was to preserve the lineage of the nobility and prevent mesalliances. It was then used to identify foreign bodies to classify non-European populations. In the nineteenth century, with $\operatorname{Renan}^{8}$ and Gobineau.

\section{Volume 2 Issue 5 - 2018}

\author{
Jacques J Rozenberg \\ Department of sociology, French National Centre for Scientific \\ Research, France
}

\begin{abstract}
Correspondence: Jacques J Rozenberg, Department of sociology, French National Centre for Scientific Research, France, Email jacrozenberg@gmail.com
\end{abstract}

Received: September 02, 2018 | Published: September 19 , 2018

There is a semantic change in terms of race. It not only refers to the human body visible differences but, due to assimilation of language families from ethnic families, a biological indelible mark. It was then used to identify the body otherness in relation to a racial standard (the Aryan) to prove the inferiority of all "races" non-Aryan. ${ }^{10}$ In this transformation of the idea of race; social Darwinism played a key theoretical role. Thus, anthropogeny haeckel promoted a selectionist struggle between races to promote the elite of humanity. ${ }^{11}$

\section{Criticism of the West-centrism body}

In response to the racist tendencies of German anthropology, Franz Boas founded in the late nineteenth century American cultural anthropology; by opposing evolutionism it dissociates the concept of culture from that of "race". ${ }^{12}$ His students will seek to demonstrate the relativity of all cultural form. So Ruth Benedict has sought to uncover the "models" (patterns) that regulate specific behaviors each company. ${ }^{13}$ Similarly, Margaret Mead was able to show the irrelevance of the Western conception of male/female ratios for Pacific societies ${ }^{14}$ and Ralph Linton ${ }^{15}$ sought, with Abram Kardiner, ${ }^{16}$ to analyze the differentiated cultural expressions apprehended through individualized forms of always consistencies. In all cases it was idiosyncratic elucidate the relationship of the individual to his culture, however striving to develop common anthropological models, but still studied regionally. ${ }^{17}$

The Nuremberg Trials have revealed the exact nature of the Nazi racial anthropology and its consequences regarding experiments on the human body. The reactions that these trials have driven on the one hand calling into almost total question of the concept of "race", ${ }^{18}$ and also promoted the strengthening of international institutions that guarantee the rights of man and those patients subject to biomedical practices. UNESCO and published in 1951 and 1952, the brochures of Michel Leiris and Claude Levi-Strauss, respectively entitled Race and Civilization and Race and History, where the notion of racism was related to the more general question of Western ethnocentrism. The latter is related to perceiving cultural differences, shocking Western values, through a pseudo-evolutionary scheme that sought to classify such differences under "stages or steps... a unique development which, from the same point, must make them converge towards the same goal". ${ }^{19}$ Ethnic strangeness, as strong as it is, must be resolved through a cumulative and reductionist approach to human history. A picture of the scale, illustrating the idea of human progress, Levi-Strauss opposes that of failures for which rider made 
the move represents only one possibility among others..$^{20}$ the cultural condition of each company is in fact a unique combination of factors that can be neither privileged nor devalued relative to other possible combinations. The relativistic conception resulting from the postNuremberg anthropology, and endorsed the idea of a total respect for all cultures, and the illegitimacy of wear on one of them that LeviStrauss would later call a "distant gaze". ${ }^{21}$

The fundamental question then arose anthropology concerned his hermeneutic dimension. Insofar ethnographic investigation is still mediated by the consciousness of the observer, its interpretation and its underlying motives criteria seem subjective to a large extent. Geertz saw fit to expand the own subjectivity to the anthropologist interpreted the content themselves and thus remove the idea of common sense all universal significance. ${ }^{22,23}$

Alongside this surreptitious passage of the relativity of interpretation process than its contents, anthropology has made a semantic shift of cultural relativism (for companies) to moral relativism (concerning the attitude of subjects) and ethics (concerning the nature of the acts). The so-called postmodernism has accentuated such a slip by proceeding from the 1980 s, in a joint protest of cognitive objectivity and universality of values. ${ }^{24}$ Perceived as illusory and are potent instruments of domination of the body, populations ${ }^{25}$ and also of all ethnic and cultural diversity. ${ }^{26}$

\section{Physical and cultural differentiation anthropology}

Cultural differences on the perception of the body, its rights and obligations have been there a few years at the center of debates about "Asian values" that include poorly integrate the concept of human rights. ${ }^{27,28}$ For the Asian thought, this concept has a very different connotation to that proposed by Western culture. The evaluation of human actions, especially when they concern the body, presupposes what determined their place in the universe and the harmony they are likely to promote it, in secondarisant notions of need and individual right. ${ }^{29,30}$ In general, the Western conception of human rights derived from an unthought preeminence of the law on the duty, in fact, empty the notion of right of any effectiveness. As Haim Cohn points out, the rights established bythe Universal Declaration Human rights is a mere statement of principle (leges nudae) has not missed being flouted at every opportunity. Own Western culture, the concept of human rights, despite its necessity and its sublimity, concerns only abstract legal body and not the actual individual bodies, asking to be guided by ethical behavior. ${ }^{31}$

Research on bioethical implications of cultural diversity and their different perceptions of the body have increased, especially since the international conference organized on this theme by UNESCO from 26 to 28 April 1995 in Sydney. ${ }^{32}$ However, the problems more difficult to manage than meets biomedicine, massively confronted with the globalization of modern pandemics, led anthropologists to question its traditional neutrality and to distinguish particular ethical relativism methodological relativism. ${ }^{33}$ Some bioethicists like Ruth Macklin, sought to bring to light a number of universal ethical principles based on human sensitivity. Thus, in line with Rousseau's anthropology Macklin shows compassion for each other and with the recognition of the humanity of man is the achievements of the Nuremberg Code that no relativism cannot deny. ${ }^{34}$ While refusing the idea of absolute ethical standards, it seeks to identify ethical behavior and provisions present in all cultures as the interests of justice and non-maleficence free. The always different application of these skills refers, beyond their diversity, common principles capable of founding a "multilevel ethics" (multilevel view of ethics). ${ }^{35,36}$ To accomplish this task well, it should identify the differentiated role held every position on the body of another, through all the cultural behaviors considered. It is in fact to promote a multidimensional perspective that takes into account the special relationship still that each company establishes between men and with the world.

In line with research in cognitive anthropology, showing that the constraints of physical reality are common to all cultures. ${ }^{37,38} \mathrm{We}$ also believe that the various forms of ethical and social constraints are common to all of humanity. Indeed, as we were able to uncover stable sets of cultural and linguistic representations converge despite ethnic diversity, ${ }^{39,40}$ and it seems possible to identify vis-à-vis the lines of another body, beyond their differences, define forms of competing reflection. Therefore, each culture should be seen as having a specific performance system whose total remains invariant, while the combination of each of the exchange elements and sets each culture own.

Such a multidimensional approach, which remains largely contextualist same time, seems particularly interesting for body anthropology. The anthropologist must take into account all the factors that determine each cultural phenomenon studied in its specificity. The Indian case of selective abortion based on sex carries a mixture of traditional philosophical-religious formations, combined with socioeconomic considerations that Western technological development allowed expressing in a gynocide perspective. Our analysis suggests that a contextual dimension, properly "anthropo-ex-centric" may help to clarify the various aspects of the issue of body-other. In fact, each company sets up its own integration criteria "very body" and individuality "normal," while rejecting "other-body" and individuals "deviant". Cultural differences on the perception of the body, its rights and obligations have been central to the debate on non-European values in general that such ill incorporate the concept of human rights ${ }^{41}$ this concept has a very different connotation to that proposed by Western culture. The evaluation of human actions, especially when they concern the body, presupposes déterùination space in the universe secondarisant the concepts of needs and individual duty.

\section{Acknowledgements}

None.

\section{Conflict of interest}

The author declares that there is no conflict of interest.

\section{References}

1. Rozenberg JJ. Bioethical and ethical issues surrounding the trials and Code of Nuremberg: Nuremberg revisited. Newyork: Edwin Mellen Press; 2003. 313 p.

2. See Spiro, Melford E. Cultural Relativism and the Future of Anthropology. Cultural Anthropology. 1986;80(3):259-286.

3. Ulin, RC. Revisiting cultural relativism: Old prospects for a new cultural critique. Anthropological Quarterly. 2007;80(3):803-820.

4. Kant E. Anthropology from a Pragmatic Point of View. Cambridge: Cambridge University Press; 2006. 280 p.

5. Herder JG. Another Philosophy of History and Selected Political Writings. In: Ioannis D, Evrigenis, Daniel Pellerin, editors. Indianapolis: Hackett Pub; 2004. 226 p.

6. Dumont L. Essays on individualism: An anthropological perspective on modern ideology. Paris: Le Seuil; 1985. p. 221-222. 
7. Beteille A. Individualism and Equality. Current Anthropology. 1986;27(2):121-134.

8. Renan E. General History and Comparative System of the Semitic languages. Paris: Troisieme edition; 1855. 287 p.

9. Gobineau JA. An Essay on the Inequality of the Human Races. Paris $1853.148 \mathrm{p}$.

10. Rozenberg JJ. Anthropology and Epistemology of other-body. In: Boetsch G, Chapuis N, Chevé D, editors. Representations of the body: The life and experiences, Standards and normality. Presses Universitaire de Nancy; 2006.148 p.

11. Haeckel E. Anthropogeny Entwicklungsgeschichte oder des Menschen. Leipzig: ITMO University press; $1874.10 \mathrm{p}$.

12. Boas F. The limitations of the comparative method of anthropology. In: Paul Bohannan, Mark Glazer, editors. High Points in Anthropology. New York: McGraw-Hill; 1988. p. 85-93.

13. Benedict R. Patterns of Culture. Newyork, Houghton Mifflin Company: Boston; $1934.290 \mathrm{p}$

14. Mead M. Sex and temperament. New York: William Morrow Mentor Company; 1935. 112 p.

15. Linton R. The tree of culture. New York: AA Knopf; 1955. 692 p.

16. Kardiner A. The Individual and His Society: The Psychodynamics of the Social Organization. The International journal of legal. 1940;50(3): 346-348.

17. Burton Michael L, White Douglas R. Regional Comparisons, Replications, and Historical Network Analysis. Cross-Cultural Research. 1991;25(1-4):55-78.

18. Gayon J. Do The Biologists need the phrase "Human Race. In: Rozenberg JJ, editor. Nuremberg Revisited Bioethical Issues Surrounding and Ethical Code of the Nuremberg Trials. New York: Mellen Press; 2003. p. 424-425.

19. Lévi Strauss C. Race and History. Paris: Gonthier; 1968. p. 23-24.

20. Ibid. p. 38 .

21. Lévi Strauss C. The View from Afar. Paris: Plon; 1983. 398 p.

22. Geertz C. The Interpretation of Cultures: Selected Essays. New York: Basic Books; 1973. p. 345-346.

23. Foley RA, Mirazón Lahr. The evolution of the diversity of cultures: Philosophical Transactions of the Royal Society B. Biological Sciences. 2011;366(1567):1080-1089.

24. Ang S, Van Dyne L. Conceptualization of cultural intelligence: Definition, distinctiveness, and nomological network. In: Ang S, Van Dyne L, editors. Handbook of Cultural Intelligence: Theory, measurement, and applications. NY: ME Sharpe; 2008. p. 3-15.

25. Soukup C. The Postmodern Flaneur and the Ethnographic Study of Hyper-Mediated Everyday Life. Journal of Contemporary Ethnography. 2012;42(2): 226-254
26. Rattansi A. Racism, Postmodernism \& Reflexive and Multiculturalism In: May S, editor. Critical Multiculturalism: rethinking and Antiracist Multicultural Education. London: Falmer; 1999. p. 77-112.

27. Bauer CF, Joanne R, Daniel A Bell. The East Asian Challenge for Human Rights. New York: Cambridge University Press; 2004. 394 p.

28. Hoon Chang Yau. Revisiting the Asian values argument used by Asian Political Leaders and Its Validity. Indonesian Quarterly. 1998;32(2):154-174.

29. Cauquelin J, Limp P, Mayer Konig B. Asian values, Encounter with Diversity. Richmond: Curzon Press; 1998. 207 p.

30. Setha M Low, Sally Engle Merry. Engaged Anthropology: Dilemmas and Diversity: An Introduction to Supplement 2. Current Anthropology. 2010;51(S2):203-226.

31. Cohn HH. Rights and Duries. In: Rozenberg JJ, editor. Bioethical Issues Surrounding the Ethical Trials and the Code of Nuremberg. Nuremberg Revisited. NY: Edwin Mellen Press; 2003. 281 p.

32. Perez de Cuellar J, et al. Our Creative Diversity. Paris: UNESCO; 1996. $64 \mathrm{p}$.

33. Massé R, Matera V. Ethnography: Experiences, representations, practices for studying cultural diversity. Introductory notes. Archivio Antropologico Mediterraneo. 2013;XVI(2):9-18.

34. Macklin R. Universality of the Nuremberg Code. In: George J Annas, Michael A Grodin, editors. The Nazi Doctors and the Nuremberg Code. New York: Oxford University Press; 1992. p. 240-257.

35. Macklin R. Against Relativism. Cultural Diversity and the Search for the Ethical Universals in Medicine. Oxford: Oxford University Press; 1999. $304 \mathrm{p}$.

36. Boudon R. Social science and the two kinds of relativism. Comparative Sociology. 2003;5(2):157-174.

37. Rodrigues Dos Santos. Know nature, nature of knowledge, contribute to cognitive anthropology. Lille: University Press of the North; 1997. 3 p.

38. Sperber D, Hirschfeld L. The cognitive foundations of stability and cultural diversity. Trends in Cognitive Sciences. 2004;8(1):40-46.

39. Lucy JA. Language Diversity and Thought: A Reformulation of the Linguistic Relativity Hypothesis. Cambridge: Cambridge University Press; 1992. 344 p.

40. Foley R. Anthropological Linguistics: An introduction. Oxford: Blackwell; 1997. $514 \mathrm{p}$

41. Bauer CF, Joanne R, Daniel A Bell. The East Asian Challenge for Human Rights. New York: Cambridge University Press; 1998. 394 p. 